\title{
FNAB in the pediatric cervical masses can delay diagnosis
}

\section{Pediatrik servikal kitlelerde İIAB tanıda gecikmeye yol açabilir}

\author{
Elif USTURALI KESKİN ${ }^{1}$ Gülden DİNIZ² ${ }^{2}$, Ali KANIK ${ }^{3}$, Ülkü KÜÇÜK² ${ }^{2}$ İbrahim ÇUKUROVA ${ }^{4}$ \\ ${ }^{1}$ Mustafakemalpaşa Devlet Hastanesi, Patoloji Laboratuvarı, Bursa \\ ${ }^{2}$ Sağlık Bilimleri Üniversitesi, İzmir Tepecik Ĕ̆gitim Araştırma Hastanesi, Patoloji Laboratuvarı, İzmir \\ ${ }^{3}$ Sağllk Bilimleri Üniversitesi, İzmir Tepecik Ĕ̈itim Araştırma Hastanesi, Pediatri Kliniği, İzmir \\ ${ }^{4}$ Sağlık Bilimleri Üniversitesi, İzmir Tepecik Eğitim Araştırma Hastanesi, Kulak Burun Boğaz, Kliniği, İzmir
}

Dear Editor,

Inflammatory myofibroblastic tumor (IMT) is a rare entity with unknown malignant potential which predominantly affects children and young adults. IMT is most frequently located in the lungs, mesentery, and omentum, at a lesser extent at head and neck region, liver, spleen, gastrointestinal/genitourinary tract, skin, breasts and central nervous system ${ }^{(1,2)}$. Histologically IMTs are characterized by proliferation of myofibroblastic spindle cells accompanied by mixed inflammatory infiltrate ${ }^{(3)}$. Any metastatic lesion of IMT has not been reported so far, while its malignant transformation has been rarely observed ${ }^{(3)}$. Spindle cell proliferation, lymphoplasmacytic infiltrates and scattered mitoses in myxoid stroma generally establish definitive diagnosis. ALK, Vimentin, SMA and cytokeratin positivity may be detected during immunohistochemical staining.

The etiology of IMT is not exactly understood, and Epstein Barr Virus (EBV) and Human herpesvirus 8 (HHV-8) have been held responsible for the development of IMT. Besides nearly in $50 \%$ of the cases with IMT clonal cytogenetic aberrations of ALK gene have been detected. ALK gene plays a role in the activation of tyrosine kinase pathway ${ }^{(4)}$. Based on these assumptions ALK-positive IMTs should be considered as a true neoplasm which should be differentiated from IMTs associated with EBV or HHV-8 ${ }^{(1-4)}$. As a low grade malignant mesenchymal tumor, the first-line treatment for IMT should be surgical resection. Ong et al. (5) evaluated, and graded head and neck IMTs based on their risks of recurrence. This grading system takes the diameter of tumor, the composition of pseudocapsule, and immunohistochemical findings into consideration. The researchers also recommended postoperative radiotherapy for patients in the high and moderate risk groups.

Most of the neck masses encountered in children have an infectious origin and resolve spontaneously ${ }^{(6)}$. However some cervical mass lesions in children carry a malignanacy potential. For example Hodgkin lymphoma (HL) generally manifests itself as a cervical mass. Histopathological examination in HL reveals that neoplastic Reed Sternberg Cells are accompanied with mixed inflammatory cells and plump fibroblasts. However typical neoplastic cells have been rarely demonstrated on aspiration slides. Therefore cytological examination hardly aids in the differential diagnosis of Hodgkin lymphoma. In addition, epithelial malignancies and their metastases, excepting thyroid papillary carcinomas, are not commonly seen in children. A fine-needle aspiration 


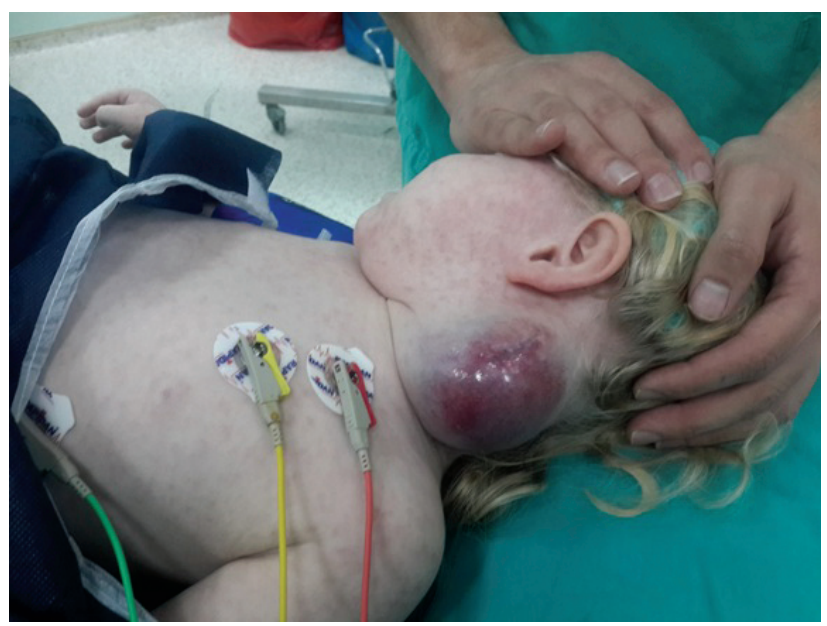

Figure 1. Left neck mass of a 3-year-old girl.

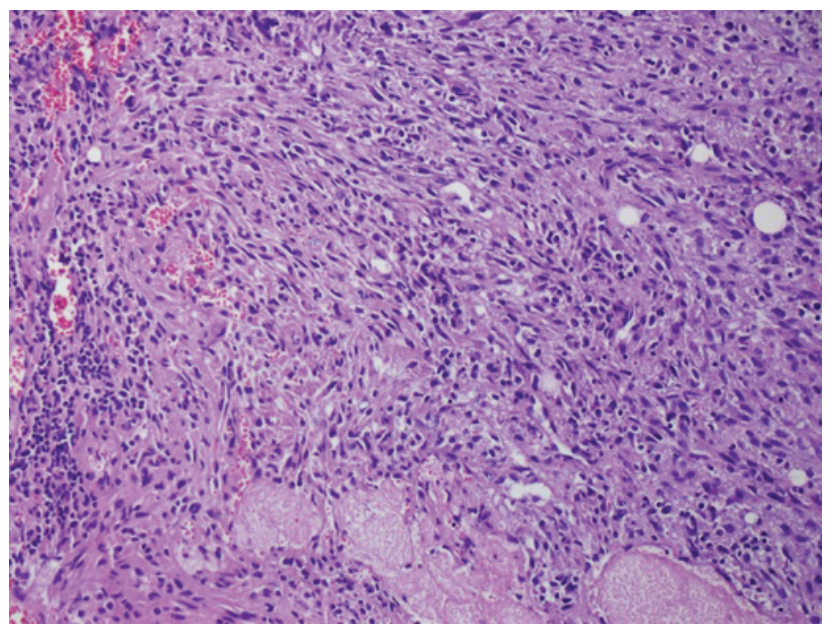

Figure 2. Tumor composed of plump spindle cells and lymphoplasmacytic infiltration (HE X 100).

biopsy (FNAB) aids in differential diagnosis, and it can be easily performed in adults with cervical subcutaneous masses. The most frequently seen metastases of epithelial tumors can be diagnosed and treatment can be planned based on FNAB results. On the contrary, the treatment of pediatric malignancies such as neuroblastoma, rhabdoid tumour or lymphomas should be performed according to the immunohistochemical features or molecular changes like gene rearrangement, mutation, and amplification. In addition, sedation or anesthesia is required for procedures of fine needle aspiration biopsy or needle biopsy in children. Therefore FNAB is not an easy and useful procedure to be applied for the diagnosis cervical masses encountered in children.
A 3-year-old girl presented with a mass on the left side of her neck that had persisted for 4 weeks despite antibiotic therapy (Figure 1). On ultrasound scanning a tumoral solid mass with a diameter of $50 \mathrm{~mm}$ was detected. At first, fine needle aspiration biopsy (FNAB) was performed (S-179/15). The result of FNAB was reported as "non-diagnostic cytology" and the total resection of the tumoral mass was advised. Two weeks later, a tru-cut biopsy (C-978/15) was performed. Cellular proliferation patterns observed in H\&E stained slides demonstrated variable characteristic features including large, bland spindle-shaped and ovoid cells arranged in fascicular, haphazard and storiform patterns. Vesicles with nuclei, and also prominent nucleoli without a high mitotic rate were striking histopathological features. A myxoid hypervascular background containing plump spindle cells, a loosely scattered lymphocytes and plasma cells was detected (Figure 2). In immunohistochemical examinations, SMA, CD68 and ALK1positive, but pan-cytokeratin, CD34, desmin, and S100 protein-negative tumor cells were discerned (Figure 3); Ki-67 proliferative index was less than 5 percent. The diagnosis of IMT was made based on histologic features and immunophenotyping characteristics, . Three weeks later, the mass was totally resected (C-1765/15). Macroscopically, tan-white soft tumoral mass had also homogenous tan-white cut surfaces. Histopathological and immunohistochemical findings were similar with those detected

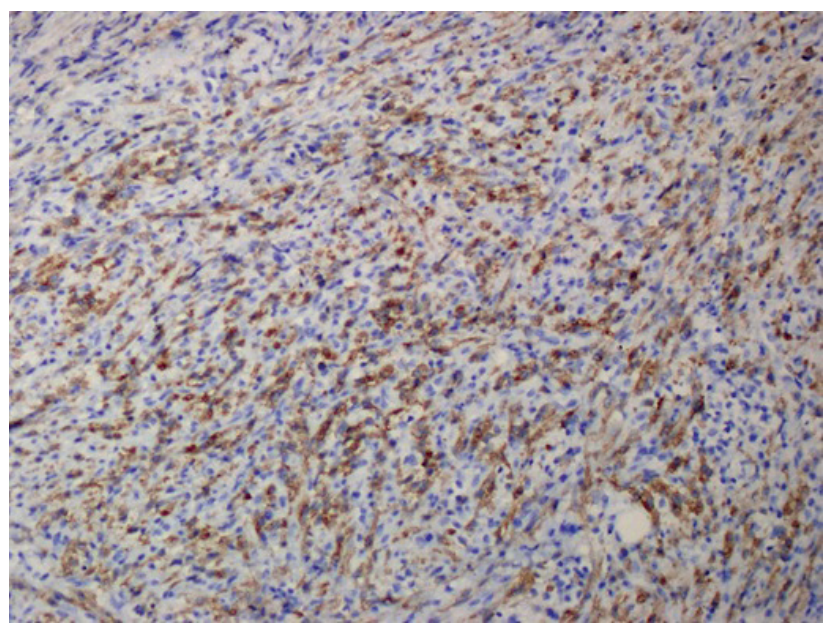

Figure 3. Note the positive ALK expressions in the spindle cells (DABx 100) 
in the tru-cut biopsy materials. The patient was diagnosed as having inflammatory myofibroblastic tumor.

Head and neck masses detected in children may develop as a result of congenital, inflammatory, infectious, vascular, or neoplastic processes. Neck masses in children can be most likely lymphoma or soft tissue tumour such as IMT which can not be diagnosed accurately by histopathological examination of fine needle aspiration biopsy specimens. Open biopsy of hematopoietic neck lesions allows complete evaluation of lymph node architecture and specific molecular features. Therefore relying on FNAB results for establishment of diagnosis does not only prevent the detailed examination of the specimen but also delays the diagnosis. Tissue biopsy should be obtained for differential diagnosis and planning the treatment. Consequently we think that diagnosis of the neck masses encountered in children should not be made based solely on fine needle aspiration biopsy results.

\section{REFERENCES}

1. Coffin $\mathrm{CM}$ and Fletcher JA. Inflammatory myofibroblastic tumour. In: WHO Pathology \& Genetics of Tumours of Soft Tissue and Bone. Fletcher CDM, Unni KK and Mertens F editors. IARC Press, Lyon, pp.90-93, 2002.

2. Gao F, Zhong R, Li GH and Zhang WD. Computed tomography and magnetic resonance imaging findings of inflammatory myofibroblastic tumors of the head and neck. Acta Radiol 2014;55(4):434-40. https://doi.org/10.1177/0284185113500165

3. Doksöz O, Mese T, Diniz G. Massive pericardial effusion caused by "inflammatory myofibroblastic tumour" in a 3-month-old child. Cardiol Young 2013;23(5):749-751. https://doi.org/10.1017/S1047951112001849

4. O'Malley DP, Poulos C, Czader M, Sanger WG and Orazi A. Intraocular inflammatory myofibroblastic tumor with ALK overexpression. Arch Pathol Lab Med 2004;128(1):e5-7, PubMed PMID: 14692830.

5. Ong HS, Ji T, Zhang CP, et al. Head and neck inflammatory myofibroblastic tumor (IMT): Evaluation of clinicopathologic and prognostic features. Oral Oncol 2012;48:141-148. https://doi.org/10.1016/j.oraloncology.201109.004.Review.

6. Curtis WJ, Edwards SP. Pediatric neck masses. Atlas Oral Maxillofac Surg Clin North Am 2015;23(1):15-20. https://doi.org/10.1016/j.cxom.2014.10.002 